\title{
MODAL INTELEKTUAL DAN KINERJA MAQASHID SYARIAH PERBANKAN SYARIAH DI INDONESIA
}

\author{
Mohammad Iqbal Bagus Ramadhan, Ahim Abdurahim dan Hafiez \\ Sofyani \\ Program Studi Akuntansi, Universitas Muhammadiyah Yogyakarta \\ Email:m.iqbal.br@umy.ac.id; ahim@umy.ac.id; hafiez.sofyani@umy.ac.id
}

\begin{abstract}
This study aims to analyze the influence of Islamic banking-intellectual capital (ibvaic) covered; capital employed, human capital, and structural capital, toward maqashid shariah performance in Islamic Banking in Indonesia. This study used all (44 banks) Islamic banking that listing in Bank Indonesia (Central Bank of Indonesia) and Otoritas Jasa Keuangan (Financial Services Authority). Data analysis used SPSS (Statistical Product and Service Solutions) with multiple regression method. The results reveal that Islamic banking-human capital have positive influence on maqashid shariah performance. However, Islamic banking-capital employed and structural capital do not have influence on maqashid shariah performance.
\end{abstract}

Keywords: Intellectual Capital, Capital employed, Human capital, Structural capital, and Maqashid syariah.

\section{PENDAHULUAN}

Kinerja perbankan di era modern saat ini tidak hanya diukur dari aspek keuangan saja, tetapi juga dari aspek non-keuangan, seperti; corporate governance, intangible assets, Economic Value Added (EVA), dan ukuran kinerja lainnya (Ulum, 2007). Pada entitas perbankan, tanggung jawab manajemen tidak hanya dilihat dari rasio-rasio tertentu dan pengungkapan akuntansi, namun juga memperhatikan aspek non-keuangan yang salah satunya pengungkapan dan pengaplikasian intellectual capital (IC) (Ulum, 2007). Pentingnya aspek intellectual capital bagi perusahaan menjadikan topik ini menarik untuk diteliti dewasa ini, khususnya terkait kontribusi IC dalam mendorong kinerja perusahaan (Ulum et al., 2016).

Pengukuran kinerja IC dalam banyak riset berfokus pada ukuran kinerja aset tak berwujud (intangible asset) seperti; goodwill, biaya akuisisi, paten, trade mark, dan royalty. Hal ini karena IC dianggap sebagai aspek strategis yang mampu menggiring perusahan untuk memperoleh dan mempertahankan keunggulan bersaing (competitive advantage) yang berkelanjutan (sustainable) (Wang dan Chang, 2005). Karenanya, pengukuran kinerja intellectual capital membuat perusahaan mampu memonitor bagian mana yang perlu ditingkatkan pada aspek IC, dengan tujuan perusahaan mampu menghasilkan keuntungan lebih besar di masa mendatang (Kamukama et al., 2011). 
Secara umum IC terdiri dari human capital (HC), structural capital (SC), dan customer capital (CC) (Bontis et al., 2000; Ulum, 2013). Menurut Widyaningrum (2004) penggunaan alat ukur IC ada beberapa metode, yaitu Edvinsson dan Sullivan (1996), Edvinson dan Malone (1997) Ross et al., (1997), Klein (1998), Winter (1998), Stewart (1998) dan yang paling sering digunakan adalah usulan Pulic (2000) yang mengukur menggunakan proksi sektor privat yang notabene bermotif keuntungan. Selain itu, metode yang ditawarkan Pulic ini hanya sesuai untuk perusahaan konvensional.

Penelitian ini sendiri bertujuan mengkaji hubungan kinerja IC dan kinerja maqashid shariahh dari perbankan syariah di Indonesia. Penelitian ini merupakan pengembangan penelitian Ulum (2013) tentang model pengukuran kinerja intellectual capital dengan iB-VAIC di perbankan syariah yang kemudian dikolaborasikan dengan penelitian Mohammed et al. (2008) tentang model pengukur kinerja perbankan syariah berdasarkan kerangka maqashid shariahh. Penelitian pada isu ini sangat menarik untuk dikaji karena isu IC pada konteks perbankan syariah masih sangat jarang dilakukan, baik secara global maupun secara khusus di Indonesia. IC di perbankan syariah saat ini lebih banyak dikaitkan dengan kinerja keuangan, kinerja sosial dan profitabilitas. Padahal, secara landasan filosofis, perbankan syariah memiliki tujuan lain selain profit dan CSR, yakni kinerja syariah.

\section{TELAAH TEORITIS DAN PENGEMBANGAN HIPOTESIS}

\subsection{RESOURCE BASED THEORY (RBT)}

Resource Based Theory adalah teori yang menggambarkan bahwa perusahaan dapat meningkatkan keunggulan bersaing dengan mengembangkan sumberdaya sehingga mampu mengarahkan perusahaan untuk bertahan secara jangka panjang (Grant, 1991). Kunci dari pendekatan RBT adalah pada strategi memahami hubungan antara sumber daya, kapabilitas, keunggulan bersaing, dan profitabilitas khususnya dapat memahami mekanisme dengan mempertahankan keunggulan bersaing dari waktu ke waktu.

Teori ini pertama kali dikemukakan oleh Wernerfelt (1984) dalam karyanya yang berjudul "A Resource-based view of the firm". Tetapi penelitian yang banyak menjadi rujukan adalah artikel karya Barney (1991) "Firm Resource and Sustained Competitive Advantage". Dijelaskan firm resource membantu perusahaan meningkatkan efisiensi dan efektivitas operasi perusahaan. Selanjutnya yaitu keunggulan kompetitif bersaing dapat dipahami dengan menanamkan pemahaman bahwa perusahaan terdiri dari elemen yang heterogen dan tak bergerak. Langkah untuk memaksimalkan keunggulan kompetitif bersaing, perusahaan harus memenuhi empat kriteria, yaitu valuable, rareness, inimitability dan non-substitutability. 


\subsection{MAQASHID SHARIAHH}

Maqashid syariah secara bahasa terdiri dari dua kata, yaitu maqashid dan alsyariah. Maqashid berarti tujuan, sedangkan al-syariah adalah jalan menuju sumber air. Sehingga dapat disimpulkan bahwa maqashid syariah adalah tujuan untuk mewujudkan kemaslahatan umat manusia baik di dunia dan di akhirat. Tetapi ulama klasik sebelum al Syatibi mendefinisikan lebih kepada padanan makna bahasa saja, sedangkan al-Ghazali, al-Amidi, dan Ibn alHajib mendefinisikan berupa mendatangkan manfaat dan menolak bahaya atau kerugian. Ada tiga tokoh ulama yang menjadi pengembang bahasan tentang maqashid syariah, yaitu Imam al-Haramayn Abu al-Ma'ali Abd Allah al-Juwayni (w. 478 H), Abu Ishaq al- Syathibi (w. 790 H) dan Muhammad al-Thahir ibn Asyur (w. 1379 H/1973 M). Munculnya tiga tokoh ini tidak mengesampingkan peran Abu Bakr al-Qaffal al-Shashi, al-Amiri, alGhazali, dan ulama lainnya yang memiliki peran besar dalam pengonsepan maqashid syariah (Mawardi, 2010).

Secara umum ketiga tokoh utama ini membagi maqashid syariah dalam tiga tingkatan, yaitu dharuriyat (kebutuhan primer), hajiyat (kebutuhan sekunder), dan tahsiniyah (kebutuhan tersier). Selanjutnya dalam kitab Al-Muwafaqat Imam al-Syatibi juga membagi ada lima elemen yang harus dipenuhi dalam maqashid syariah, yaitu al-aql (pikiran), addien (agama), nafs (jiwa), nasl (keturunan) dan maal (harta) (Capra, 2001).

Pengertian syariah dan fungsinya bagi manusia menurut al-Syatibi tertuang dalam kitabnya al-Muwwafaqat sebagai berikut:

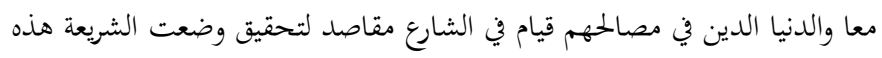

"Sesungguhnya syariat itu ditetapkan bertujuan untuk tegaknya (mewujudkan) kemashlahatan manusia di dunia dan Akhirat"

Pada bagian lain al-Syatibi juga menyebutkan bahwa:

$$
\text { العباد لمصالح مشروعة الاحكام }
$$

"Hukum-hukum diundangkan untuk kemashlahatan hamba".

Kemudian dalam merumuskan kinerja perusahaan dalam konteks maqashid al-daruriyyat dan perspektif maqashid syariah disini kami menggunakan pendapat al-Syatibi ada lima elemen pokok yang harus dipenuhi, yaitu agama (al-din), jiwa (al-nafs), keturunan (al-nasl), harta (al$m a l)$ dan akal $(a l \text { - } a q l)^{1}$. Dari kelima elemen tersebut lalu dituangkan dalam suatu tabel kriteria kinerja perusahaan dalam perspektif maqashid syariah yang disertai indikator yang diformulasi oleh Mohammed et al. (2015) dalam bentuk indeks maqashid syariah.

\footnotetext{
${ }^{1}$ Lebih jelasnya baca buku karya Abu Ishaq al-Syatibi, Al-Muwafaqat, (Beirut: Darul Ma'rifah, 1997), jilid 1-2, h. 324
} 


\subsection{CAPITAL EMPLOYED DAN KINERJA MAQASHID SYARIAH PERBANKAN SYARIAH}

Capital employed memiliki peran pada kinerja perusahaan, yaitu karyawan telah memberi value added yang baik kepada nasabah berupa pelayanan jasa yang baik. Dalam konteks hubungan capital employed dan maqashid syariah adalah pelayanan baik yang sesuai tata krama Islam dan standar pelayanan perbankan syariah, dimana akan menimbulkan kepercayaan nasabah terhadap bank. Tata krama dan standar pelayanan yang sesuai adab Islam disini contohnya memberi salam terhadap nasabah dan saling keterbukaan dalam kegiatan akad pembiayaan maupun investasi. Hal ini juga sudah diatur dalam Undang-Undang No. 21 Tahun 2008 tentang Perbankan Syariah, dimana setiap kegiatan maupun transaksi perbankan syariah harus sesuai prinsip syariah serta mengandung nilai keadilan, kebersamaan, pemerataan dan kemanfaatan.

Berdasarkan teori RBT yaitu perusahaan akan mempu bersaing jika mampu memanfaatkan keunggulan kompetitif yang tidak dimiliki perusahaan lain (Ulum, 2013; 2014; 2016). Dalam konteks ini perusahaan perbankan syariah akan mampu bersaing di bisnis perbankan jika terus meningkatkan pelayanan yang sesuai tata krama Islam, serta mengedepankan prinsip-prinsip islam dalam setiap kegiatan maupun transaksi atau langkah yang akan diambil. Dari penjelasan tersebut peneliti mengajukan hipotesis sebagai berikut:

$\mathrm{H}_{1}$ : $\quad$ Capital employed berpengaruh positif terhadap kinerja maqashid syariah perbankan syariah.

\subsection{HUMAN CAPITAL DAN KINERJA MAQASHID SYARIAH PERBANKAN SYARIAH}

Human capital dalam penelitian ini menjelaskan tingkat pemanfaatan kemampuan pengetahuan karyawan untuk menghasilkan kekayaan secara berkelanjutan dan meningkatkan nilai perusahaan. Pemanfaatan kemampuan pengetahuan karyawan yang dimaksud dilakukan dalam bentuk pemberian insentif (semacam timbal balik) atas jasa karyawan yang sudah digunakan oleh perusahaan (Ulum et al., 2016). Dalam hal ini perusahaan sudah memenuhi hak karyawan berupa pemberian gaji, tunjangan serta pendidikan maupun pelatihan lain untuk meningkatkan keterampilan mereka. Hal ini juga sejalan terhadap konsep yang dijelaskan oleh RBT bahwa jika karyawan mendapatkan gaji dan tunjangan yang layak serta pendidikan tambahan yang mumpuni, maka karyawan akan bekerja secara baik dan produktif yang mengarah penciptaan kinerja maqashid syariah yang baik pula (Grant, 1991; Ulum, 2007). Dari penjelasan tersebut peneliti mengajukan hipotesis sebagai berikut:

$\mathrm{H}_{2}$ : Human capital berpengaruh positif terhadap kinerja maqashid syariah perbankan syariah. 


\subsection{STRUCTURAL CAPITAL DAN KINERJA MAQASHID SYARIAH PERBANKAN SYARIAH}

Structural capital memiliki peran terhadap kinerja perusahaan yaitu perusahaan sudah memberikan infrastruktur dan sistem atau prosedur yang baik untuk mendukung kerja kayawan secara efektif. Infrastruktur dan prosedur pelayanan nasabah yang baik disini maksudnya infrastruktur yang dimiliki sudah lengkap bahkan terdepan (Ulum, 2014). Infratruktur yang lengkap tentu juga prosedur pelayanan juga harus baik yaitu sesuai tuntunan Islam dan tetap mengedepankan aspek maqashid syariah didalamnya seperti sikap jujur dalam pelayanan serta pemberian informasi kepada nasabah. Halhal tersebut sudah termasuk dalam melindungi pikiran, agama dan jiwa nasabah, sehingga nasabah percaya bahwa perbankan memiliki komitmen yang tinggi terhadap nasabahnya.

Mendasarkan teori RBT bahwa perusahaan akan mampu bersaing jika mampu memanfaatkan keunggulan kompetitif yang tidak dimiliki perusahaan lain (Bontis et al., 2000). Dalam konteks ini perusahaan perbankan syariah akan mampu bersaing di bisnis perbankan jika terus meningkatkan structural capital yang berupa infrastruktur dan sistem atau prosedur transaksi yang sesuai tatanan syariah dengan nasabah maka akan semakin baik pula kinerja maqashid syariah yang dihasilkan. Semakin baik infrastruktur dan efisien prosedur transaksi dengan nasabah maka akan semakin baik pula respon nasabah terhadap bank, sehingga fluktuasi transaksi dengan nasabah terus berjalan lancar dan terus meningkatkan kinerja keuangan bank. Kinerja keuangan yang baik akan menghasilkan income yang tinggi sehingga perbankan akan memenuhi aspek lain selain internal perusahaan, seperti aspek maqashid syariah demi menjaga konsep syariah perbankan syariah dari riba' dan hal haram lainnya (Ulum 2014; 2016; Mohammed et al., 2008; 2015). Dari penjelasan tersebut peneliti mengajukan hipotesis sebagai berikut:

$\mathrm{H}_{3}$ : Structural capital berpengaruh positif terhadap kinerja maqashid syariah perbankan syariah.

\section{METODE PENELITIAN}

Sampel penelitian ini adalah perbankan syariah yang masuk dalam kategori Bank Umum Syariah (BUS) yang terdaftar di Bank Indonesia (Central Bank of Indonesia) and Otoritas Jasa Keuangan (Financial Fervices Authority). Data penelitian diambil dari informasi yang terdapat pada laporan keuangan dan laporan tahunan sampel dari tahun 2012 sampai 2015.

Variabel dependen dalam penelitian ini adalah kinerja maqashid shariah yang pengukurannya berupa Indeks Maqashid shariah dan kriteria yang dikembangkan oleh Mohammed et al. (2008). Kinerja maqashid shariah perbankan syariah dapat didefinisikan sebagai tingkat bank syariah dalam mencapai tujuan syariah Islam (maqashid syariah). Adapun instrumen pengukuran kinerja maqashid shariah yang digunakan pada penelitian ini 
mengacu pada model Mohamed et al. (2015) disajikan pada Tabel 1. Pengukuran maqashid shariahh dilakukan dengan pendekatan analisis konten dan memberikan skor 1 jika item pada maqashid shariahh dipenuhi, dan skor 0 jika tidak.

Adapun variabel Independen penelitian ini adalah Intellectual Capital yang merujuk pada model Bontis et al (2000) yang membaginya menjadi tiga aspek, yakni; human capital (HC), structural capital (SC), dan customer capital (CC). Lebih lanjut, Ulum (2013) mengembangkan intellectual capital menggunakan pendekatan standar akuntansi syariah sehingga cocok untuk perbankan syariah di Indonesia atau pengukurnya disebut Islamic BankingValue Added Intellectual Capital (iB-VAIC), yang terdiri dari capital employed (CE), human capital (HC), structural capital (SC).

Tabel 1. Penerapan Maqashid shariahh Index pada Bank Syariah

\begin{tabular}{|c|c|c|c|}
\hline $\begin{array}{l}\text { Konsep } \\
\text { (tujuan) }\end{array}$ & Dimensi & Elemen & Rasio kinerja \\
\hline \multirow{4}{*}{$\begin{array}{l}\text { Mendidik } \\
\text { Individu }\end{array}$} & \multirow{2}{*}{$\begin{array}{l}\text { D1. Memajukan } \\
\text { pengetahuan }\end{array}$} & $\begin{array}{l}\text { E1. Bantuan } \\
\text { pendidikan }\end{array}$ & $\begin{array}{l}\text { R1. Bantuan } \\
\text { pendidikan/total } \\
\text { beban }\end{array}$ \\
\hline & & $\begin{array}{l}\text { E2. } \\
\text { Penelitian }\end{array}$ & $\begin{array}{l}\text { R2. Beban } \\
\text { penelitian/total } \\
\text { beban }\end{array}$ \\
\hline & $\begin{array}{l}\text { D2. Menerapkan } \\
\text { dan } \\
\text { meningkatkan } \\
\text { keahlian baru }\end{array}$ & E3. Pelatihan & $\begin{array}{l}\text { R3. Beban } \\
\text { pelatihan/total } \\
\text { beban }\end{array}$ \\
\hline & $\begin{array}{l}\text { D3. } \\
\text { Menciptakan } \\
\text { kesadaran akan } \\
\text { bank syariah }\end{array}$ & E4. Publikasi & $\begin{array}{l}\text { R4. Beban promosi/ } \\
\text { total beban }\end{array}$ \\
\hline \multirow{3}{*}{$\begin{array}{l}\text { Menegakkan } \\
\text { Keadilan }\end{array}$} & $\begin{array}{l}\text { D4. } \\
\text { Pengembalian } \\
\text { yang adil }\end{array}$ & $\begin{array}{l}\text { E5. Return } \\
\text { yang adil }\end{array}$ & $\begin{array}{l}\text { R5. Bagi hasil } \\
\text { belum dibagi } \\
\text { /pendapatan atau } \\
\text { investasi bersih }\end{array}$ \\
\hline & $\begin{array}{l}\text { D5. Produk dan } \\
\text { pelayanan yang } \\
\text { terjangkau }\end{array}$ & $\begin{array}{l}\text { E6. Fungsi } \\
\text { distribusi }\end{array}$ & $\begin{array}{l}\text { R6. Pembiayaan } \\
\text { mudharabah \& } \\
\text { musyarakah/total } \\
\text { pembiayaan }\end{array}$ \\
\hline & $\begin{array}{l}\text { D6. } \\
\text { Menghilangkan } \\
\text { unsur-unsur } \\
\text { negatif yang } \\
\text { dapat } \\
\text { menciptakan } \\
\text { ketidakadilan }\end{array}$ & $\begin{array}{l}\text { E7. Produk } \\
\text { bebas bunga }\end{array}$ & $\begin{array}{l}\text { R7. Pendapatan } \\
\text { bebas bunga/total } \\
\text { pendapatan }\end{array}$ \\
\hline $\begin{array}{l}\text { Memelihara } \\
\text { Kemaslahatan }\end{array}$ & D7. Profitabilitas & $\begin{array}{l}\text { E8. Rasio } \\
\text { laba }\end{array}$ & $\begin{array}{l}\text { R8 laba bersih/total } \\
\text { asset }\end{array}$ \\
\hline
\end{tabular}




\begin{tabular}{|c|c|c|c|}
\hline $\begin{array}{l}\text { Konsep } \\
\text { (tujuan) }\end{array}$ & Dimensi & Elemen & Rasio kinerja \\
\hline & $\begin{array}{l}\text { D8. Retribusi } \\
\text { pendapatan \& } \\
\text { kesejahteraan }\end{array}$ & $\begin{array}{l}\text { E9. } \\
\text { Pendapatan } \\
\text { individu }\end{array}$ & $\begin{array}{l}\text { R9. Zakat yang } \\
\text { dibayarkan/aset } \\
\text { bersih }\end{array}$ \\
\hline & $\begin{array}{l}\text { D9. Investasi di } \\
\text { sektor riil }\end{array}$ & $\begin{array}{l}\text { E10. Rasio } \\
\text { investasi di } \\
\text { sektor riil }\end{array}$ & $\begin{array}{l}\text { R10. Investasi } \\
\text { sektor riil/total } \\
\text { investasi }\end{array}$ \\
\hline
\end{tabular}

Sumber: Mohammed et al. (2015)

Tabel 2. Bobot Masing-Masing Tujuan dan Elemen

\begin{tabular}{|c|c|c|c|}
\hline Tujuan & obot Tujuan (\%) & Elemen & $\begin{array}{c}\text { Bobot Elemen } \\
(\%)\end{array}$ \\
\hline \multirow{5}{*}{$\begin{array}{l}\text { T1. Pendidikan } \\
\text { Individu }\end{array}$} & \multirow{5}{*}{30} & $\begin{array}{l}\text { E1. Bantuan } \\
\text { Pendidikan }\end{array}$ & 24 \\
\hline & & E2. Penelitian & 27 \\
\hline & & E3. Training & 26 \\
\hline & & E4. Publikasi & 23 \\
\hline & & Total & 100 \\
\hline \multirow{4}{*}{$\begin{array}{l}\text { T2. Menciptakan } \\
\text { Keadilan }\end{array}$} & \multirow{4}{*}{41} & E5. Fair Return & 30 \\
\hline & & E6. Fair Price & 32 \\
\hline & & $\begin{array}{l}\text { E7. Produk bebas } \\
\text { bunga }\end{array}$ & 38 \\
\hline & & Total & 100 \\
\hline \multirow{5}{*}{$\begin{array}{l}\text { T3. Kesejahteraan } \\
\text { Publik }\end{array}$} & \multirow{5}{*}{29} & E8. Rasio laba & 30 \\
\hline & & $\begin{array}{l}\text { E9. Transfer } \\
\text { Pendapatan }\end{array}$ & 33 \\
\hline & & E10. Rasio & \\
\hline & & $\begin{array}{l}\text { Investasi sektor } \\
\text { riil }\end{array}$ & 37 \\
\hline & & Total & 100 \\
\hline Total & 100 & & \\
\hline
\end{tabular}

Sumber: Mohammed et al.(2008)

Tabel 3. Pengukuran variabel Islamic Banking-Value Added Intellectual Capital (iB-VAIC)

\begin{tabular}{lll}
\hline \multicolumn{1}{c}{ Item iB-VAIC } & \multicolumn{1}{c}{ Konsep } & \multicolumn{1}{c}{ Rumus } \\
& & iB-VA= OP + EC + \\
& & D $+\mathbf{A}$ \\
& & Keterangan: \\
Islamic banking- & Ukuran nilai tambah laba & OP = operating profit \\
Value Added (iB- & yang dihasilkan oleh & (laba operasi/laba \\
VA) & karyawan bagi perusahaan & usaha) \\
& & EC = employee costs \\
& & (beban karyawan) \\
\hline
\end{tabular}




\begin{tabular}{|c|c|c|}
\hline Item iB-VAIC & Konsep & Rumus \\
\hline & & $\begin{array}{l}\mathrm{D}=\text { depreciation } \\
\text { (depresiasi) } \\
\mathrm{A}=\text { amortization } \\
\text { (amortisasi) }\end{array}$ \\
\hline $\begin{array}{l}\text { Islamic banking- } \\
\text { Value Added Capital } \\
\text { employed (iB- } \\
\text { VACA) }\end{array}$ & $\begin{array}{l}\text { iB-VACA adalah indikator } \\
\text { untuk mengukur VA dari } \\
\text { pegawai yang berhubungan } \\
\text { langsung dengan customer } \\
\text { atau pemberi layanan } \\
\text { kepada penerima layanan } \\
\text { perusahaan. Rasio ini } \\
\text { menunjukkan kontibusi } \\
\text { yang dibuat oleh setiap unit } \\
\text { dari capital employed (CE) } \\
\text { terhadap value added } \\
\text { perusahaan }\end{array}$ & $\begin{array}{l}\quad i B-V A C A=\frac{V A}{C E} \\
\text { Keterangan: } \\
\text { iB-VACA = rasio } \\
\text { dari iB-VA terhadap } \\
\mathrm{CE} \\
\mathrm{iB}-\mathrm{VA}=\text { value added } \\
\mathrm{CE}=\text { Total Ekuitas }\end{array}$ \\
\hline $\begin{array}{l}\text { Islamic banking- } \\
\text { Value Added Human } \\
\text { Capital (iB-VAHU) }\end{array}$ & $\begin{array}{l}\text { iB-VAHU adalah } \\
\text { kemampuan pegawai dalam } \\
\text { memberikan jasa serta } \\
\text { berhubungan baik dengan } \\
\text { customer. Rasio ini } \\
\text { menunjukkan produktifitas } \\
\text { HC atas dana yang sudah } \\
\text { diinvestasikan perusahaan } \\
\text { untuk menghasilkan value } \\
\text { added. }\end{array}$ & $\begin{array}{l}\quad i B-V A H U=\frac{V A}{H C} \\
\text { Keterangan: } \\
\text { iB-VAHU = rasio } \\
\text { dari iB-VA terhadap } \\
\text { HC } \\
\text { iB-VA = Value } \\
\text { Added } \\
\text { HC = Beban } \\
\text { Karyawan }\end{array}$ \\
\hline $\begin{array}{l}\text { Islamic banking- } \\
\text { Structural Capital } \\
\text { Value Added (iB- } \\
\text { STVA) }\end{array}$ & $\begin{array}{l}\text { iB-STVA adalah prasarana } \\
\text { yang dimiliki perusahaan } \\
\text { untuk memenuhi kebutuhan } \\
\text { pasar. Rasio ini mengukur } \\
\text { jumlah structural capital } \\
\text { (SC) yang dibutuhkan untuk } \\
\text { menghasilkan satu rupiah } \\
\text { dari iB-VA dan merupakan } \\
\text { indikasi bagaimana } \\
\text { keberhasilan SC dalam } \\
\text { penciptaan nilai perusahaan, } \\
\text { dalam hal ini adalah } \\
\text { perbankan syariah }\end{array}$ & $\begin{array}{l}\quad i B-S T V A=\frac{S C}{V A} \\
\text { Keterangan: } \\
\text { STVA= rasio dari SC } \\
\text { terhadap iB-VA } \\
\text { SC = selisih antara } \\
\text { (iB-VA) dan HC } \\
\text { iB-VA = Value } \\
\text { Added }\end{array}$ \\
\hline
\end{tabular}

Pengukuran Islamic Banking-Value Added Intellectual Capital (iBVAIC) yang dikembangkan Ulum (2013) sebagaimana disajikan pada Tabel 3. Sedangkan pengujian hubungan antar variabel dilakukan dengan analisis 
regresi menggunakan software SPSS 23. Persamaan regresinya adalah sebagai berikut:

$$
\gamma=\alpha+\beta 1 \chi 1+\beta 2 \chi^{2}+\beta 3 \chi 3+\varepsilon
$$

Keterangan:

$\gamma \quad=$ Kinerja Maqashid Syariah Perbankan Syariah

$\chi^{1}=$ Capital Employed (iB-VACA)

$\chi^{2}=$ Human Capital (iB-VAHU)

$\chi^{3}=$ Structural Capital (iB-STVA)

$\alpha=$ Konstanta

$\beta \quad=$ Koefisien regresi

$\varepsilon \quad=$ Error

\section{HASIL DAN PEMBAHASAN}

\subsection{GAMBARAN UMUM OBJEK PENELITIAN}

Sampel pada penelitian ini adalah bank syariah yang masuk dalam kategori bank umum syariah. Bank umum syariah sendiri adalah bank syariah yang sudah melepaskan diri dengan bank induk yang operasionalnya dijalankan secara konvensional (non-syariah). Data yang digunakan periode 2012-2015. Dengan demikian, total data sampel yang diperoleh adalah sebanyak 44 dari laporan keuangan dan laporan tahunan. Statistik deskriptif dari sampel penlitian ini disajikan pada Tabel 4 .

Tabel 4. Descriptive Statistics

\begin{tabular}{lrrrrr}
\hline & $\mathrm{N}$ & Minimum & Maximum & Mean & $\begin{array}{c}\text { Std. } \\
\text { Deviation }\end{array}$ \\
\hline maqashid_syariah & 31 & .13567 & .38564 & .2483826 & .06145791 \\
\hline Ib-vaca & 31 & -.47358 & .92435 & .2674166 & .26614537 \\
\hline Ib-vahu & 31 & - & 3.48700 & .8743171 & 2.52038224 \\
& 31 & -.64544 & 1.97517 & .3572032 & .46195119 \\
\hline Ib-stva & 31 & & & & \\
\hline Valid N (listwise) & 31266 & & & & \\
\hline
\end{tabular}

Tabel 5. Classic Assumption Test Results

\begin{tabular}{lc}
\hline Normality Test & \\
Asymp. Sig. (2-tailed) & 0,169 \\
\hline Multicolinearity test & \\
VIF ib-vaca & 1,746 \\
VIF ib-vahu & 1,757 \\
VIF ib-stva & 1,037 \\
\hline Auto correlation test & \\
$\quad$ Durbin-Watson & 2.080 \\
\hline Heteroscedasticity & \\
\hline
\end{tabular}




$\begin{array}{ll}\text { Sig. ib-vaca } & 0,068 \\ \text { Sig. ib-vahu } & 0,138 \\ \text { Sig. ib-stva } & 0,304\end{array}$

\subsection{HASIL UJI REGRESI}

Sebelum dilakukan analisis hasil pengujian hipotesis, terlebih dahulu dilakukan pengujian asumsi klasik yaitu pengujian normalitas, uji multikolinearitas, uji autokorelasi dan uji heteroskedastisitas. Berdasarkan hasil uji normalitas, ditemukan nilai signifikansi sebesar 0,169 atau lebih dari 0,05 , sehingga data disimpulkan berdistribusi normal. Hasil pengujian juga menunjukkan bahwa data tidak mengandung multikolinearitas yang ditunjukkan dengan nilai variance inflation factor (VIF) di bawah nilai 10 . Begitu pula hasil pengujian tidak terdapat autokorelasi dan heteroskedastisitas. Hal ini menunjukkan bahwa data dapat digunakan untuk pengujian hipotesis (Ghozali, 2006).

Tabel 6. Hasil Uji Regresi

\begin{tabular}{lccc}
\hline \multicolumn{1}{c}{ Hypotheses } & $\begin{array}{c}\text { Standardized } \\
\text { Coefficients }\end{array}$ & p-Value & Conclusion \\
\hline ib-vaca $>\mathrm{ms}$ & -.809 & .000 & Not Supported \\
\hline ib-vahu $>\mathrm{ms}$ & .834 & .000 & Supported \\
\hline ib-stva $>\mathrm{ms}$ & -.021 & .880 & Not Supported \\
\hline Coefficients of Determination & & .4333 \\
\hline
\end{tabular}

Dari hasil uji regresi yang disajikan pada Tabel 6, ditemukan bahwa koefesien determinasi dari variabel indpenden dalam menjelaskan variabel dependen adalah 0,4333 atau $43,33 \%$. Sedangkan sisanya $(56,67 \%)$ sharia dijelaskan oleh variabel-variabel lain. Dari Tabel 6 ditemukan bahwa capital employed tidak berpengaruh terhadap kinerja maqashid shariah perbankan syariah. Simpulan ini berdasarkan nilai koefesien dari hubungan iB-VACA terhadap MS yang bernilai negatif $(-0,809)$. Hal ini bisa jadi dikarenakan proses rutinitas operasi perbankan yang terstruktur dan prosedur kerja perusahaan hanya sebatas formalitas dan bukan karena didasarkan prinsip maqashid syariah. Jika ditinjau dari Resource-based theory (RBT), maka dapat diindikasikan bahwa perbankan syariah di Indonesia mengelola sumber dayanya berdasarkan konsep konvensional. Hal ini sangat logis mengingat mayoritas perbankan syariah di Indonesia adalah hasil peranakan dari perbankan konvensional, sehingga praktik-praktik manajerial yang diadopsi di perbankan syariah berasal dari perbankan konvensional. Hal ini juga bisa jadi mengindikasikan adanya sharia labeling, atau "brand" syariah pada perbankan hanya sebatas penciptaan nilai perusahaan semata, dan bukan berorientasi pada substansi dari maqashid shariahh (Sofyani dan Akbar, 2015). Jika mengacu kepada praktik di lapangan, pelayanan perbankan syariah di Indonesia memang dirasakan tidak memiliki perbedaan yang jauh dengan perbankan konvensional. Perbedaan perbankan syariah dan 
konvensional lebih dominan kepada produk perbankan ketimbang pada aspek pelayanan kepada nasabah.

Alasan lain yang juga dapat menjelaskan tidak berpengaruhnya capital employed terhadap kinerja maqashid shariahh adalah karena pengukuran rasio capital employed dan kinerja maqashid shariahh masih terpaku pada standar BI, dimana tidak ada perbedaan secara aspek finansial dengan perbankan konvensional yaitu berorientasi profit. Dengan demikian secara empiris hasil ini menunjukkan bahwa efisiensi penggunaan modal kerja di perbankan syariah di Indonesia, terutama bagi karyawan, tidak berkontribusi kepada pemenuhan maqashid shariah yang lebih baik. Selanjutnya, penelitian ini menemukan bahwa human capital berpengaruh positif secara signifikan terhadap kinerja maqashid shariah perbankan syariah. Hal ini menunjukkan bahwa pengalokasian beban kepegawaian pada pengukuran human capital yang dimiliki perbankan syariah mampu menciptakan value added yang tinggi pada perusahaan. Lebih lanjut, perusahaan sudah menunjukkan bahwa mampu menciptakan value efficiency pada sumber daya manusianya, seperti keahlian, pengetahuan, jaringan, dan olah pikir karyawannya sesuai maqashid syariah (Ulum et al. 2008).

Implikasi dari semakian tingginya rasio alokasi beban kepegawaian, dalam konteks ini ukuran human capital berarti pemenuhan maqashid syariah akan semakin baik pula. Hal ini dipertegas dari hasil statistik deskriptif yang menunjukkan bahwa rata-rata perbankan syariah mengalokasin biaya gaji dan tunjangan karyawan sebesar $87,4 \%$. Ssecara empiris hasil ini menunjukkan bahwa mensejahterakan karyawan dengan layak telah sesuai kriteria memenuhi pendidikan individu dan menjaga jiwa dan akal karyawannya, yang secara tak langsung juga melindungi keturunan karyawannya. Aspek ini sangat sejalan dengan konsep maqashid shariah (Mawardi, 2010). Temuan ini juga menverivikasi RBT yang menjelaskan bahwa perusahaan telah mampu mengembangkan sumber daya manusia yang dimiliki, seperti keahlian dan kompetensi karyawannya agar dapat mencapai kinerja maqashid syariah (Ulum et al., 2016). Dampak positifnya, strategi keunggulan bersaing berasaskan maqashid shariah yang telah dilakukan perusahaan telah mampu menciptakan keunggulan bersaing yang valuable, inimitability dan non-substitutability. Lebih lanjut, temuan ini juga dapat ditinjau dari sudut pandang teori isomorfisme institusional. Penciptaan kinerja maqashid shariah yang baik dari human capital menunjukkan bahwa pemberiaan gaji, tunjangan, pelatihan, dan pendidikan bagi karyawannya telah mampu menggiring perbankan syariah untuk mencapai tujuan substantifnya selain laba, yakni maqashid shariah (Sofyani dan Akbar, 2015).

Selanjutnya, temuan ketiga penelitian ini menyimpulkan bahwa structural capital tidak berpengaruh terhadap kinerja maqashid shariah di perbankan syariah. Hal ini mengindikasikan bahwa dari total biaya atau investasi infrastruktur dan sistem kegiatan operasi yang dikeluarkan perusahaan tidak mampu memberi value added terhadap pemenuhan maqashid syariah. Hal ini mungkin terjadi karena perusahaan fokus pada prioritas membangun kondisi internal perusahaan secara efektif dan efisien. 
Dengan terciptanya kondisi internal yang baik diharapkan dapat menciptakan value added yang tinggi pula dimasa mendatang, sehingga sustainability perbankan syariah dapat terjaga. Hal ini menjadi masuk akal mengingat usia perbankan syariah yang ada di Indonesia masih sangat relatif muda dan memerlukan fokus pada keberlangsungan usaha.

\section{SIMPULAN}

Penelitian ini menemukan bahwa Islamic banking-human capital berpengaruh positif terhadap kinerja maqashid syariah. Sedangkan Islamic banking-capital employed dan structural capital tidak berpengaruh terhadap kinerja maqashid syariah. Intellectual capital yang ada diperbankan syariah, seperti sumber daya manusia, sistem dan operasional sangat mungkin masih mengadopsi dan turunan dari perbankan konvensional sebagai induk perusahaan. Lebih lanjut, dari proses adopsi budaya dan transfer tenaga kerja mengakibatkan sudut pandang yang dibawa masih konvensional dan belum mengarah pada maqashid syariah.

Sebagaimana penelitian empiris, penelitian ini juga memiliki keterbatasan, antara lain: pertama, sampel penelitian ini hanya sebatas perbankan syariah yang ada di Indonesia. Akibatnya, kemampuan generalisasi dari hasil riset ini masih lemah untuk skala Internasional. Karenanya, penelitian selanjutnya sebaiknya dilakukan di Negara-negara lain untuk menemukan hasil penelitian yang memiliki cakupan lebih luas. Kedua, penelitian ini hanya menguji satu variabel independen terhadap maqashid shariah. Diperlukan penelitian lanjutan yang menambahkan variabel lain, seperti; kinerja corporate social responsibility, umur perusahaan, total aset, leverage, management laba, dan sharia government, untuk melihat apakah ada efek variabel-variabel lain tersebut yang memediasi atau memoderasi antara hubungan intellectual capital terhadap kinerja maqashid syariah. Terakhir, penelitian ini hanya mengukur maqashid shariah menurut rumusan yang dibuat oleh Mohamed et al. (2015). Padahal, konsep maqashid shariah dapat saja dirumuskan berbeda oleh akademisi lain. Karenanya, penelitian selanjutnya akan semakin menarik jika dilakukan kajian lebih mendalam tentang konsep maqashid shariah di era modern sekarang ini, khususnya terkait lembaga bisnis syariah.

\section{DAFTAR PUSTAKA}

Barney, J. (1991). Firm resources and sustained competitive advantage. Journal of management, 17(1), 99-120.

Bontis, N., Chua Chong Keow, W., \& Richardson, S. (2000). Intellectual capital and business performance in Malaysian industries. Journal of intellectual capital, 1(1), 85-100. 
Edvinsson, Leif, and Patrick Sullivan. (1996). Developing a model for managing intellectual capital." European management journal, 14(4), 356-364.

Edvinsson, L., \& Malone, M. S. (1997). Intellectual capital: realizing your companyl's true value by finding its hidden brainpower.

Grant, R. M. (1991). The resource-based theory of competitive advantage: implications for strategy formulation. California management review, 33(3), 114-135.

Kamukama, N., Ahiauzu, A., \& Ntayi, J. M. (2011). Competitive advantage: mediator of intellectual capital and performance. Journal of intellectual capital, 12(1), 152-164.

Klein, D. A. (1998). The strategic management of intellectual capital. Routledge.

Mawardi, A. I. (2010). Fiqh minoritas: fiqh al-aqaliyat dan evolusi maqashid al-syariah dari konsep ke pendekatan. LKiS.

Mohammed, Mustafa Omar, Dzuljastri Abdul Razak and Fauziah Md Taib. (2008). The Performance Measures of Islamic Banking Based on the Maqasid Framework", Paper of IIUM International Accounting Conference (INTAC IV) held at Putra Jaya Marroitt.

Mohammed, M. O., \& Taib, F. M. (2015). Developing Islamic banking performance measures based on Maqasid al-Shari'ah framework: Cases of 24 selected banks. Journal of Islamic Monetary Economics and Finance, 1(1), 55-77.

Pulic, A. (2000). Basic information on VAIC ${ }^{\mathrm{TM}}$. Available from: http:// www.vaic-on.net. [Last retrieved 2000 Dec 023].

Ross, J., Ross, G., Dragonetti, N., \& Edvinsson, L. (1997). Intellectual capital. Macmillam Buisness, London.

Stewart, T., \& Ruckdeschel, C. (1998). Intellectual capital: The new wealth of organizations.

Ulum, I. (2007). Pengaruh intellectual capital terhadap kinerja keuangan perusahaan perbankan di Indonesia. (Doctoral dissertation, Program Pascasarjana Universitas Diponegoro).

Ulum, I. (2013). Model Pengukuran Kinerja Intellectual Capital Dengan IBVAIC Di Perbankan Syariah", INFERENSI, 7(1), 185-206.

Ulum, I., Ghozali, I., Purwanto, A. (2014). Intellectual capital performance of indonesian banking sector: A modified VAIC (M-VAIC) perspective. Asian Journal of Finance and Accounting, 6(6), 103-123.

Ulum, I., Rizqiyah, R., \& Jati, A. W. (2016). Intellectual Capital Performance: A Comparative Study between Financial and Non- 
Financial Industry of Indonesian Biggest Companies. International Journal of Economics and Financial Issues, 6(4), 1436-1439.

Wang, W. Y., \& Chang, C. (2005). Intellectual capital and performance in causal models: Evidence from the information technology industry in Taiwan. Journal of intellectual capital, 6(2), 222-236.

Wernerfelt, B. (1984). A resource-based view of the firm", Strategic management journal, 5(2), 171-180.

Widyaningrum, A. (2004) Modal Intelektual", Jurnal Akuntansi dan Keuangan Indonesia. 1(1), 16-25.

Winter, S., \& Teece, D. J. (1998). Knowledge and competence as strategic assets. The strategic management of intellectual capital, 187. 